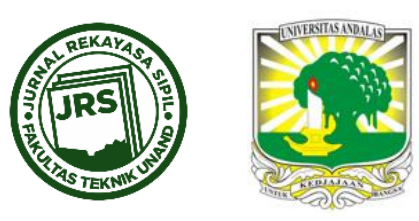

\title{
STUDI PERENCANAAN BANGUNAN BRONJONG PADA TIKUNGAN SUNGAI DI DESA MEUNASAH BULOH
}

\author{
MEYLIS SAFRIANI ${ }^{1} \&$ DEWI PURNAMA SARI ${ }^{2}$ \\ ${ }^{1}$ Program Studi Teknik Sipil Universitas Teuku Umar(\meylissafriani@utu.ac.id) \\ 2Program Studi Teknik Sipil Universitas Teuku Umar (dewipurnamasari@utu.ac.id)
}

Naskah diterima : 9 Juli 2018. Disetujui: 22 November 2018. Diterbitkan : 8 Desember 2018

\begin{abstract}
Erosi yang terjadi setiap tahun pada tebing sungai di Desa Meunasah Buloh, Kabupaten Aceh Barat semakin parah terutama pada bagian tikungan sungai. Hal ini dikarenakan aliran sungai pada tikungan sungai lebih cepat jika dibandingkan dengan sungai yang berpenampang lurus. Bangunan perkuatan tebing sungai untuk mengurangi erosi pada Desa Meunasah Buloh direncanakan menggunakan bronjong. Tujuan dari penelitian ini adalah untuk menentukan desain bronjong yang sesuai dalam mengurangi erosi tebing sungai di bagian tikungan atau belokan sungai di desa tersebut. Berdasarkan survei awal, perkebunan masyarakat yang berada di dekat tepi sungai terkikis akibat erosi, bahkan ada perumahan penduduk yang jaraknya sudah mendekati sungai. Oleh karena itu, dibutuhkan perencanaan bangunan pengaman tebing sungai tipe bronjong untuk mengatasi erosi. Analisa yang dilakukan meliputi analisa curah hujan rencana, debit banjir rencana, profil muka air banjir, desain ukuran bronjong, dan stabilitas bronjong. Desain dan ukuran bronjong yang sesuai adalah bronjong bentuk I kode D dengan dimensi 2,0 x 1,0 x 1,0 m dan ukuran batu sebesar $40 \mathrm{~cm}$. Hasil perhitungan stabilitas terhadap guling diperoleh FSguling sebesar 3,49 dimana nilai ini lebih besar dari 1,5. Berdasarkan hasil perhitungan dapat dilihat bahwa struktur konstruksi bronjong aman terhadap gaya guling. Hasil perhitungan stabilitas bronjong terhadap gaya geser diperoleh struktur konstruksi bronjong aman terhadap geser dimana nilai FSgeser sebesar 1,58 dimana nilai ini lebih besar dari 1,5. Nilai kapasitas dukung ultimit yang diperoleh sebesar 16,84 $\mathrm{kg} / \mathrm{cm} 2$ sedangkan tegangan maksimum yang diperoleh $2,57 \mathrm{~kg} / \mathrm{cm} 2$. Hasil perhitungan diperoleh tegangan maksimum lebih kecil dari tegangan izin maka daya dukung tanah untuk pondasi bronjong sebagai perkuatan tebing sungai aman. Berdasarkan hasil analisis, menunjukkan bahwa struktur desain konstruksi bronjong aman terhadap gaya guling, gaya geser, dan daya dukung tanah. Peletakan bangunan bronjong pada tebing sungai bagian tikungan/belokan sungai di Desa Meunasah Buloh mulai cross sungai A11 - A19 sepanjang $620 \mathrm{~m}$.
\end{abstract}

Kata kunci : erosi, tebing sungai, tikungan sungai, bronjong, stabilitas bronjong

\section{PENDAHULUAN}

Erosi dapat berubah menjadi bencana apabila laju erosi lebih cepat dari pada laju pembentukan tanah, sehingga berangsur-angsur mengikis tanah. Hal ini berdampak buruk 
bagi masyarakat terutama bagi masyarakat yang tinggal di sekitar bantaran aliran sungai. Tingkat kerusakan yang ditimbulkan dari erosi tebing sungai perlu ditekan agar tidak menambah kerusakan lainnya. Tingkat kerusakan ini dapat dikurangi dengan dibangunnya bangunan perkuatan tebing sungai yang berfungsi untuk melindungi tebing terhadap gerusan arus sungai dan mencegah terjadinya erosi tebing pada tebing sungai. Ada beberapa cara dalam menangani erosi tebing sungai yaitu dengan membangun perkuatan tebing sungai seperti talud, turap, gabion, dan krib.

Salah satu desa di Kabupaten Aceh Barat yang sungainya semakin lebar akibat terjadinya erosi pada tebing sungai adalah Desa Meunasah Buloh, Kecamatan Kaway XVI, Kabupaten Aceh Barat. Sungai Krueng Meureubo merupakan sungai yang mengalir pada desa ini dimana sungai ini berada di Daerah Aliran Sungai (DAS) Krueng Meureubo. Erosi yang terjadi setiap tahun pada tebing sungai di desa tersebut semakin parah. Bagian yang tererosi parah yaitu pada bagian tikungan sungai. Hal ini dikarenakan aliran sungai pada belokan atau tikungan sungai lebih cepat jika dibandingkan dengan sungai yang berpenampang lurus. Berdasarkan survei awal, perkebunan masyarakat yang berada di dekat tepi sungai terkikis akibat erosi, bahkan ada perumahan penduduk yang jaraknya sudah mendekati sungai. Perkebunan masyarakat yang terkikis oleh aliran sungai dapat dilihat pada Gambar 1. Selain beberapa dampak di atas, juga terdapat dampak lain yang disebabkan oleh erosi tebing sungai sehingga diperlukan suatu solusi untuk meminimalisir terjadi penggerusan tebing sungai secara terus menerus terutama di musim penghujan.

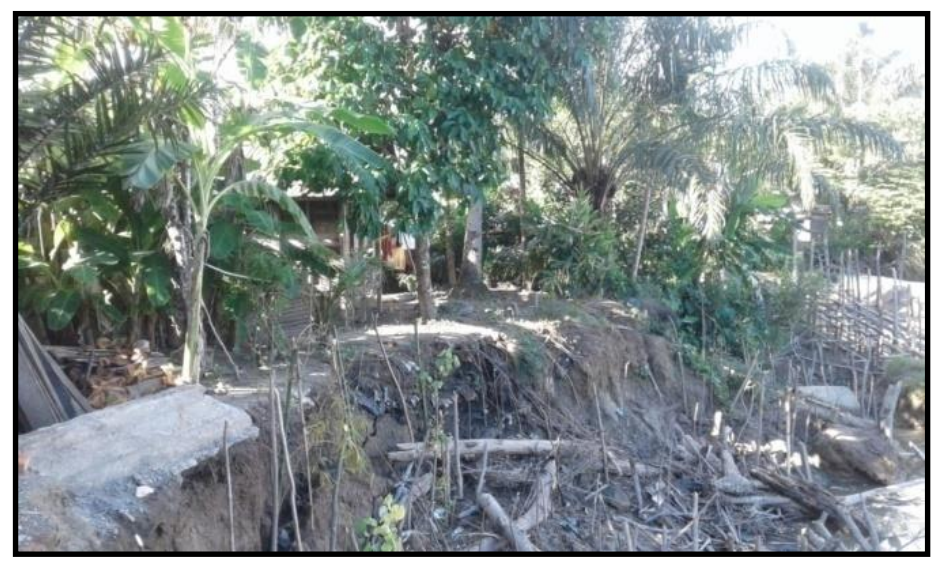

Gambar 1. Kondisi tebing sungai pada bagian tikungan/belokan sungai yang telah tererosi

Erosi tebing sungai (streambank erosion) merupakan pengikisan tanah pada tebing-tebing sungai dan penggerusan dasar sungai oleh aliran air sungai. Penyebab terjadinya erosi tebing sungai oleh adanya gerusan aliran sungai yang berkorelasi dengan kecepatan aliran sungai dan oleh adanya longsoran tanah pada tebing sungai. Beberapa faktor yang menyebabkan terjadinya erosi antara lain, iklim (terutama intensitas hujan), topografi, karakteristik tanah, vegetasi penutup tanah, dan tataguna lahan (Asdak, 2010).

Beberapa peneliti telah melakukan studi tentang desain bronjong, Rosihun (2011), membandingkan hasil desain talud bronjong yang sudah ada dengan hasil desain perhitungan sendiri pada Talud Bronjong pada Sungai Gadjah Wong UIN Sunan Kalijaga Yogyakarta. Hasil penelitian yang diperoleh Talud Bronjong pada Sungai Gadjah Wong UIN Sunan Kalijaga Yogyakarta kurang aman ditinjau dari stabilitas pergeseran jika kawat bronjong dianggap tidak diikat, namun kenyataannya kawat bronjong saling diikat sesamanya, Talud Bronjong pada Sungai Gadjah Wong UIN Sunan Kalijaga Yogyakarta 
aman terhadap stabilitas penggulingan karena $\mathrm{Fgl}>\mathrm{Sf}$, dan aman terhadap daya dukung tanah karena qmax = qa yaitu $581,4=833,64 \mathrm{kN} / \mathrm{m} 2$.

Benyamin,dkk. (2017) meneliti tentang Perkuatan Tebing Menggunakan Bronjong Di Sungai Manikin. Berdasarkan debit kala ulang banjir yang didapat maka dihitung stabilitas kekuatan bronjong, terhadap debit banjir yang terjadi, dan diadakan analisis kontrol terhadap stabilitas krib bronjong pada potongan I-I diperoleh momen tahan sebesar 67,100 ton meter dan momen guling 8,487 ton meter, serta besarnya gaya vertikal $=37,400$ ton dan gaya horizontal $=5,004$ ton, pada potongan II-II diperoleh momen tahan sebesar 62,700 ton meter dan momen guling 8,926 ton meter, serta besarnya gaya vertikal $=35,200$ ton dan gaya horizontal $=5,579$ ton, pada potongan III-III diperoleh momen tahan sebesar 50,325 ton meter dan momen guling 12,621 ton meter, serta besarnya gaya vertikal $=29,700$ ton dan gaya horizontal $=5,513$ ton, mampu untuk menahan terhadap guling, eksentrisitas, daya dukung tanah dan terhadap geser.

Penelitian lain tentang bronjong dilakukan oleh Murri, dkk (2014) mengenai stabilitas lereng di Sungai Gajah Putih, Surakarta dengan metode Bishop pada kondisi sebelum longsor, kondisi setelah pemasangan bronjong oleh pihak Dinas Pekerjaan Umum (DPU) dan kondisi variasi I-IV. Hasil yang diperoleh menunjukkan bahwa lereng yang dipasang bronjong mempunyai nilai SF lebih besar daripada lereng tanpa bronjong. SF kondisi sebelum longsor $<\mathrm{SF}$ setelah pemasangan bronjong oleh Dinas Pekerjaan Umum (DPU) < SF kondisi variasi III. Perbandingan SF pada kondisi variasi III dengan nilai SF kondisi setelah pemasangan bronjong oleh DPU akibat beban mati menghasilkan beda SF sebesar ffl20\%, sementara akibat beban mati+beban hidup menghasilkan beda SF sebesar ffl11\%. Pemasangan bronjong mampu meningkatkan stabilitas lereng sungai Gajah Putih, sehingga pemasangannya sangat tepat untuk mengatasi kelongsoran yang terjadi dan pemasangan bronjong pada kaki lereng sungai Gajah Putih sebaiknya memasang bronjong dengan kondisi variasi III karena relatif lebih aman.

Studi ini menggunakan bronjong sebagai perkuatan tebing sungai yang tererosi. Bronjong adalah kotak yang terbuat dari anyaman kawat baja berlapis seng yang pada penggunaannya diisi batu-batu untuk pencegah erosi yang dipasang pada tebing-tebing dan tepi-tepi sungai (Dinas PU, 1999). Dalam perencanaan perkuatan tebing sungai beberapa hal yang perlu diperhatikan adalah bronjong aman terhadap gaya guling, gaya geser, gaya angkat dan kemampuan daya dukung tanah.

Penelitian terhadap kondisi tanah terutama di bagian tikungan sungai di Desa Meunasah Buloh perlu dilakukan untuk dapat direncanakan dimensi bronjong yang sesuai. Desain bronjong yang sesuai dan aman dapat ditinjau dari segi stabilitas dan daya dukung sebagai bangunan perkuatan perlindungan tebing sungai sehingga hasil desain tersebut mampu diaplikasikan dalam menanggulangi permasalahan yang terjadi di desa tersebut.

\section{STABILITAS BANGUNAN BRONJONG}

Bangunan bronjong yang akan direncanakan dan dihitung stabilitasnya, terlebih dahulu dianalisis curah hujan rencana, debt banjir rencana, dan profil muka air.

\subsection{Curah hujan Rencana dan Debit Banjir Rencana}

Perhitungan curah hujan rencana dapat dilakukan dengan analisis statistik yaitu dengan menghitung parameter statistik dari data yang dianalisis. Dalam ilmu statistik dikenal beberapa macam analisis sebaran dan banyak digunakan dalam hidrologi. Analisis sebaran 
tersebut adalah distribusi normal, log normal, sebaran gumbel, dan sebaran log Pearson III (Harto, 2000).

Debit banjir rencana (design flood) adalah besarnya debit yang direncanakan melewati penampang sungai dengan periode ulang tertentu. Menurut Kodoatie (2002), besarnya debit banjir ditentukan berdasarkan curah hujan dan aliran sungai antara lain besarnya intensitas hujan, dan luas DAS. Debit banjir rencana untuk daerah aliran sungai dengan luas $>100 \mathrm{~km}^{2}$ dan kurang dari $1000 \mathrm{~km}^{2}$ adalah dengan menggunakan metode Melchior. Rumus umum yang dipakai pada metode Melchior adalah:

$$
\begin{aligned}
& \mathrm{Q}_{\mathrm{T}}=\alpha \times \beta \times q \times A \times \frac{\mathrm{RT}}{200} \\
& \beta=\frac{180+0,75 \mathrm{~A}}{150+\mathrm{A}}
\end{aligned}
$$

dengan :

$\mathrm{QT}=$ debit banjir (m3/dt) dengan periode ulang $\mathrm{T}$ tahun

$\alpha \quad=$ koefisienlimpasan air hujan $(0,52)$

$\beta=$ koefisien reduksi daerah untuk curah hujan DAS

$\mathrm{q} \quad=$ intensitas hujan maksimum (m3/km2/det)

$\mathrm{A} \quad=$ luas DAS $(\mathrm{km} 2)$

RT = curah hujan rencana untuk periode ulang $\mathrm{T}$ tahunan $(\mathrm{mm})$

Untuk perhitungan profil muka air atau tinggi muka air dari satu potongan melintang ke potongan sungai berikutnya dapat dilakukan dengan metode tahapan standar (standard step method). Dengan mengetahui karakteristik aliran dan kekasaran pada satu tampang sungai, maka kecepatan dan kedalaman aliran di tampang yang lain dapat dihitung (Triatmodjo, 2010). Persamaan energi ditulis sebagai berikut:

$$
\mathrm{Y}_{1}+\mathrm{Z}_{1}+\frac{\mathrm{V}_{1}^{2}}{2 g}=\mathrm{Y}_{2}+\mathrm{Z}_{2}+\frac{\mathrm{V}_{2}^{2}}{2 g}+\mathrm{h}_{\mathrm{f}}
$$

dengan:

$\mathrm{Y} 1, \mathrm{Y} 2$ = elevasi air di penampang melintang $(\mathrm{m})$

$\mathrm{Z1}, \mathrm{Z2}$ = elevasi penampang utama $(\mathrm{m})$

$\mathrm{V} 1, \mathrm{~V} 2$ = kecepatan rata-rata $(\mathrm{m} / \mathrm{s})$

$\mathrm{g}=$ percepatan gravitasi $(\mathrm{m} / \mathrm{s} 2)$

$\mathrm{hf} \quad=$ kehilangan tinggi energi $(\mathrm{m})$

\subsection{Stabilitas Bronjong}

Nilai kedalaman air yang digunakan dalam perencanaan bronjong adalah nilai kedalaman air terbesar yang sudah dihitung pada tinggi muka air banjir dari setiap rentang cross pada pias sungai. Nilai kecepatan air rata-rata digunakan nilai rata-rata dari kecepatan air pada saluran yang telah dihitung sebelumnya pada perhitungan profil muka air banjir. Setelah mendapatkan nilai diameter ukuran batu, maka dipilih ukuran bronjong yang sesuai (Freeman dan Fischenich, 2000). Ukuran batuan yang digunakan untuk bronjong dapat ditentukan dari persamaan sebagai berikut:

$$
D_{m}=S_{f} C_{s} C_{v} d\left[\left(\frac{\gamma_{s}}{\gamma_{w}}\right)^{0,5} \frac{v_{a}}{\sqrt{g^{2} K_{1}}}\right]^{2,5}
$$




$$
\mathrm{C}_{\mathrm{v}}=1,283-0,2 \log \left(\frac{\mathrm{R}}{\mathrm{W}}\right)
$$

dengan:

Cs $\quad=$ koefisien stabilitas $(0,1)$

$\mathrm{Cv} \quad=$ koefisien distribusi kecepatan (min. 1)

$\mathrm{Dm} \quad=$ diameter batuan rata-rata $(\mathrm{m})$

$\mathrm{d} \quad=$ kedalaman aliran lokal $(\mathrm{m})$

$\mathrm{g} \quad=$ percepatan gravitasi $(\mathrm{m} / \mathrm{s} 2)$

K1 = faktor koreksi kemiringan tebing

$\mathrm{R} \quad=$ radius rencana tikungan saluran utama terhadap centerline $(\min 150 \mathrm{~m})$

Sf = faktor keamanan (min. 1,1)

va = kecepatan rata-rata di sungai utama $(\mathrm{m} / \mathrm{s})$

$\mathrm{W}=$ lebar permukaan air $(\mathrm{m})$

$\gamma \mathrm{s} \quad=$ berat jenis tanah $(\mathrm{kg} / \mathrm{m} 3)$

$\gamma \mathrm{w}=$ berat jenis air $(\mathrm{kg} / \mathrm{m} 3)$

Perencanaan bangunan pengaman tebing sungai tipe bronjong memperhatikan beberapa hal diantaranya stabilitas terhadap guling, stabilitas terhadap geser, dan stabilitas terhadap daya dukung tanah. Apabila desain bronjong belum memenuhi persyaratan stabilitas, maka diperlukan perhitungan ulang terhadap ukuran dimensi bronjong kembali (Freeman dan Fischenich, 2000).

Stabilitas bronjong dapat diketahui dengan melaukan analisis terlebih dahulu gaya-gaya yang bekerja pada bronjong - gaya-gaya tersebut diantaranya, gaya akibat berat bronjong itu sendiri, gaya akibat tanah lateral, dan gaya akibat tekanan hidrostatis (gaya ini disebabkan dari tekanan air sugai). Menurut Rankine (1897) dalam Hardiyatmo (2011), tekanan tanah lateral adalah gaya yang di timbulkan oleh akibat dorongan tanah di belakang struktur penahan tanah. Besarnya tekanan lateral sangat dipengaruhi oleh perubahan displacement) dari dinding penahan sifat-sifat tanahnyaperhitungan tekanan tanah lateral. Persamaan umum yang dapat digunakan untuk mengihitung tekanan tanah aktif dan pasif disajikan sebagai berikut.

$$
\begin{aligned}
& P_{a}=\frac{1}{2} x H^{2} x k a x \gamma \mathrm{s} \\
& P_{p}=\frac{1}{2} x H^{2} x k p x \gamma \mathrm{s}
\end{aligned}
$$

Untuk mendapatkan konstruksi bronjong yang stabil perlu diselidiki stabilitas terhadap momen guling. Momen guling dihitung dengan menggunakan Persamaan 6 dengan syarat momen guling harus lebih besar dari atau sama dengan 1,5. Untuk mendapatkan konstruksi yang stabil perlu juga diselidiki stabilitas terhadap momen gesernya. Momen geser dihitung dengan menggunakan Persamaan 7 dengan syarat momen geser harus lebih besar dari atau sama dengan 1,5. Stabilitas bronjong terhadap guling (overturning) ditentukan dengan Persamaan berikut.

$$
\mathrm{FS}_{\text {guling }}=\frac{M_{t}}{M_{g}} \geq 1,5
$$

dengan:

$\mathrm{Mt}=$ Momen $\operatorname{tahan}(\mathrm{tm})$ 
$\mathrm{Mg}=$ Momen guling $(\mathrm{tm})$

Stabilitas bronjong terhadap geser (sliding) ditentukan dengan Persamaan berikut.

$$
\mathrm{FS}_{\text {geser }}=\frac{\sum V}{\sum H} \geq 1,5
$$

dengan:

$\mathrm{V}=$ besar gaya yang bekerja secara vertikal pada sekeliling bangunan $(\mathrm{t})$

$\mathrm{H}$ = besar gaya yang bekerja secara horizontal pada sekeliling bangunan $(\mathrm{t})$

Penentuan nilai keamanan dari bahaya keruntuhan dapat menggunakan Persamaan Terzaghi (Hardiyatmo, 2006). Daya dukung tanah dalam hal ini dinyatakan sebagai kapasitas dukung ultimit bangunan bronjong ditentukan dengan Persamaan berikut.

$$
\begin{aligned}
& \mathrm{e}=\frac{\mathrm{B}}{2}-\left(\frac{\mathrm{M}_{\mathrm{t}}-\mathrm{M}_{\mathrm{g}}}{\sum V}\right) \leq \frac{\mathrm{B}}{6} \\
& q_{u}=\mathrm{c} N_{C}+\gamma \mathrm{D} N_{q}+0,5 \gamma \mathrm{BN}_{\gamma} \\
& \tau_{\text {izin }}=\frac{\mathrm{q}_{\mathrm{u}}}{3} \\
& q_{\text {maks }}=\frac{\sum V}{\mathrm{~B}}\left(1+\frac{6 \mathrm{e}}{\mathrm{B}}\right) \leq \tau_{\text {izin }}
\end{aligned}
$$

dimana:

$\mathrm{e} \quad=$ eksentrisitas

$\mathrm{B} \quad=$ lebar bawah tubuh bangunan (m)

$\mathrm{q}_{\mathrm{u}} \quad=$ kapasitas dukung ultimit $\left(\mathrm{kg} / \mathrm{m}^{2}\right)$

$\mathrm{N}_{\mathrm{c}}, \mathrm{N}_{\mathrm{q}}, \mathrm{N}_{\gamma}$ = faktor kapasitas dukung Terzaghi;

$\gamma \quad=$ berat volume tanah $\left(\mathrm{kg} / \mathrm{m}^{3}\right)$;

$\mathrm{D} \quad=$ kedalaman pondasi $(\mathrm{m})$;

$\tau_{\text {izin }} \quad=$ tegangan izin $\left(\mathrm{kg} / \mathrm{m}^{2}\right)$

$\mathrm{q}_{\text {maks }}=$ tekanan maksimum $\left(\mathrm{kg} / \mathrm{m}^{2}\right)$

\section{METODOLOGI PENELITIAN}

Penelitian ini berlokasi di Desa Meunasah Buloh dengan mengamati kondisi tebing sungainya. Desa Meunasah Buloh merupakan salah satu desa yang berada di dalam Kecamatan Kaway XVI, Kabupaten Aceh Barat, Provinsi Aceh. Secara geografis Desa Meunasah Buloh terletak pada posisi 04013'0" Lintang Utara (LU) dan 96¹0'0" Bujur Timur. Desa Meunasah Buloh secara administratif berbatasan langsung dengan 4 desa lainnya, yaitu Desa Padang Mancang, Desa Peunia, Desa Mesjid dan Desa Keude Pasi.

\subsection{Pengumpulan Data}

Pengumpulan data pada studi ini terdiri dari pengumpulan data primer dan data sekunder. Data primer dalam perencanaan ini berupa data tanah dan data fisik sungai. Adapun untuk data sekunder yaitu data yang didapat dari berbagai sumber ataupun lembaga terkait dan diperlukan dalam menyelesaikan studi perencanaan ini. Data sekunder dalam studi ini meliputi data data curah hujan dan data topografi.

Data tanah diperlukan dalam menghitung stabilitas bangunan pengaman tebing sungai, karena tanah merupakan tempat penyaluran gaya serta momen dari struktur bagian atas. 
Data mekanika tanah didapat dari hasil survei pengujian sampel tanah di lokasi yang diperoleh dari hasil pengujian tanah di Laboratorium Mekanika Tanah Jurusan Teknik Sipil Unsyiah.

Data fisik sungai merupakan data kondisi sungai tersebut, meliputi panjang sungai, lebar sungai, kedalaman sungai, karakteristik tebing sungai dan luas tampang sungai. Data ini nantinya akan langsung di ambil di lokasi penelitian. Data curah hujan ini diperoleh dari pencatatan pada Stasiun Meteorologi, Klimatologi dan Geofisika Stasiun Chut Nyak Dhien Meulaboh. Data hujan yang diperoleh adalah data curah hujan maksimum bulanan (mulai dari tahun 2005 - 2017). Data ini akan dipergunakan untuk menghitung curah hujan rencana dan debit banjir rencana.

Data topografi yang diperlukan untuk studi ini terdiri dari Peta topografi, peta DAS, peta Layout Sungai Krueng Meureubo. Peta-peta ini digunakan untuk mengetahui ketinggian suatu tempat, untuk memperkirakan tingkat kecuraman atau kemiringan lereng sungai, dan luas DAS. Peta topografi diperoleh dari BAPPEDA Aceh Barat. Peta DAS dan peta Layout Sungai Krueng Meureubo diperoleh dari BWSS Provinsi Aceh.

\subsection{Analisis Data}

Analisis data hidrologi yang diperlukan dalam perencanaan bangunan bronjong seperti analisis data curah hujan rencana, debit banjir rencana, dan profil muka air banjir. Curah hujan rencana adalah curah hujan terbesar tahunan di dalam suatu daerah dengan kala ulang tertentu, yang dipakai sebagai dasar perhitungan penelitian suatu dimensi bangunan. Perhitungan debit rencana dilakukan setelah curah hujan rencana diperoleh.

Desain ukuran batu pada bronjong akan diterima jika tegangan geser dasar saluran lebih kecil dari tegangan geser kritis dasar saluran dan tegangan geser tebing lebih kecil dari tegangan geser kritis tebing. Jika nilainya kurang, maka bronjong tidak dapat menahan deformasi, sehingga ukuran batuan harus diperbesar untuk membatasi deformasi. Perletakan bronjong pada studi perencanaan ini dilakukan pada tebing sungai bagian tikungan Sungai Krueng Meureubo di Desa Meunasah Buloh yang mengalami erosi terparah. Tahapan-tahapan yang dilakukan dalam desain bronjong meliputi penentuan diameter ukuran batu rerata, penentuan kontrol terhadap geser dengan menggunakan diameter ukuran batu yang telah dihitung, serta kontrol terhadap stabilitas dasar bronjong untuk mengetahui bronjong memerlukan filter kerikil atau tidak.

Perhitungan momen guling dan momem geser, nilai yang diperoleh harus lebih besar dari 1,5. Perhitungan daya dukung tanah terhadap dimulai dengan menghitung eksentrisitas, dilanjutkan dengan menghitung kapasitas dukung ultimit. Hasil dari kapasitas dukung ultimit ini digunakan untuk mengetahui nilai tegangan izin, lalu nilai tekanan maksimum dihitung dan nilai yang dihasilkan harus lebih kecil atau sama dengan nilai tegangan izin.

\section{HASIL DAN PEMBAHASAN}

Hasil perhitungan dan pembahasan meliputi perhitungan curah hujan rencana, debit banjir rencana, analisis hidrolika profil muka air banjir, perencanaan perkuatan tebing sungai menggunakan bronjong, analisa stabilitas bangunan bronjong, dan lokasi desain bronjong, 


\subsection{Analisis Debit Banjir Rencana}

Curah hujan rencana dianalisis pada periode ulang 2 tahun, 5 tahun, 10 tahun, 25 tahun, dan 50 tahun. Setelah mendapatkan nilai curah hujan bulanan maksimum, dilakukan analisis frekuensi. Dari analisis frekuensi ini dapat diketahui distribusi mana yang cocok digunakan pada penelitian ini. Untuk itu, dilakukan beberapa perhitungan distribusi diantaranya distribusi normal, distribusi log normal, distribusi gumbel dan distribusi log pearson III. Hasil perhitungan debit banjir rencana disajikan pada Tabel 1.

Tabel 1. Hasil perhitungan debit banjir rencana

\begin{tabular}{cccccc}
\hline \multirow{2}{*}{ Parameter } & \multicolumn{5}{c}{ Kala Ulang (Tahun) } \\
\cline { 2 - 6 } & 2 & 5 & 10 & 25 & 50 \\
\hline $\mathrm{tc}$ & 11.9 & 11.9 & 11.9 & 11.9 & 11.9 \\
\hline$\alpha$ & 0.6 & 0.6 & 0.6 & 0.6 & 0.6 \\
\hline $\mathrm{q}$ & 4.27 & 4.27 & 4.27 & 4.27 & 4.27 \\
\hline$\beta$ & 0.855 & 0.855 & 0.855 & 0.855 & 0.855 \\
\hline $\mathrm{A}$ & 490.13 & 490.13 & 490.13 & 490.13 & 490.1 \\
\hline $\mathrm{Rt}$ & 113.14 & 147.36 & 174.64 & 214.67 & 248.8 \\
\hline $\mathrm{Qt}$ & 607.77 & 791.62 & 938.14 & 1153.2 & 1336 \\
\hline
\end{tabular}

Debit banjir rencana dianalisis dengan menggunakan metode Melchior. Pemilihan metode ini dilakukan karena luas DAS pada lokasi studi penelitian adalah $491 \mathrm{~km} 2$ (luas DAS lebih dari $100 \mathrm{~km} 2$ dan kurang dari $1000 \mathrm{~km} 2$ ). Beberapa variable yang digunakan dalam menghitung debit banjir rencana periode ulang $\mathrm{T}$ tahun adalah koefisien limpasan air hujan, koefisien reduksi daerah untuk curah hujan DAS, intensitas hujan maksimum, luas DAS dan curah hujan rencana untuk periode ulang $\mathrm{T}$ tahun.

\subsection{Lokasi Perencanaan Bronjong}

Gerusan yang terjadi pada dasar tebing sungai terutama pada bagian tikungan sungai dapat dikurangi melalui pembuatan atau pembangunan bronjong. Selain itu, tujuan dibangunnya bronjong untuk mencegah limpasan yang terjadi sepanjang sungai karena adanya perubahan bentuk alur sungai. Bangunan bronjong direncanakan dipasang sepanjang tikungan sungai pada sisi kiri alur sungai.

Berdasarkan peta layout Sungai Krueng Meureubo, direncanakan peletakan bangunan bronjong pada tebing sungai pada bagian tikungan/belokan sungai di Desa Meunasah Buloh mulai cross sungai A11 - A19 sepanjang $620 \mathrm{~m}$. Hal ini bertujuan untuk melindungi tebing sungai dari gerusan air yang terjadi ketika banjir, sehingga proses terjadinya erosi tebing pada sungai dapat dikurangi. Hasil desain peletakan bronjong disajikan pada Gambar 2.

\subsection{Perencanaan bangunan bronjong}

Nilai debit banjir periode ulang 25 tahun diperoleh sebesar $1153.19 \mathrm{~m} 3 / \mathrm{s}$ setelah dilakukan analisa hidrologi dan analisa hidrolika. Selanjutnya sebelum dilakukan analisis stabilitas bronjong, maka langkah awal yang diperlukan adalah mendesain ukuran batu. Analisis ukuran batu sebagai berikut.

$$
\begin{aligned}
& D_{m}=S_{f} C_{s} C_{v} d\left[\left(\frac{\gamma_{s}}{\gamma_{w}}\right)^{0,5} \frac{v_{a}}{\sqrt{g^{d K_{1}}}}\right]^{2,5} \\
& D_{m}=1,1 \times 0,1 \times 1,18 \times 8,5\left[(0,67)^{0,5} \times 0,818\right]^{2,5}=0,4 \text { meter }
\end{aligned}
$$




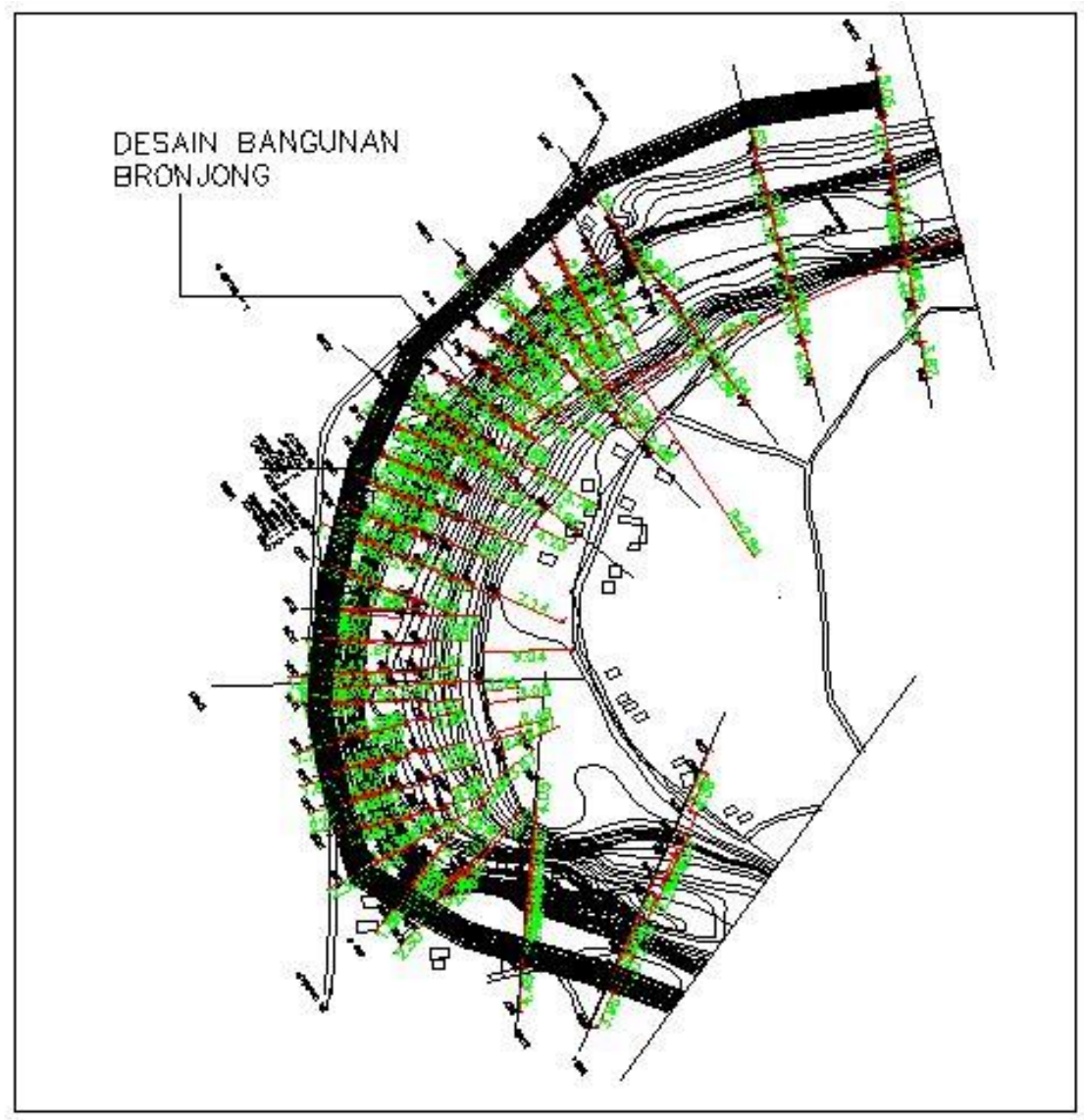

Gambar 2. Perencanaan peletakan bangunan bronjong pada tebing sungai pada bagian tikungan/belokan sungai di Desa Meunasah Buloh

Perhitungan kontrol terhadap geser, tegangan geser tebing, tegangan geser kritis dasar saluran, dan tegangan geser kritis tebing diperoleh setelah dilakukan pemilihan ukuran batu. Adapun nilai kontrol terhadap geser diperoleh $\tau \_b=14,57 \mathrm{~kg} / \mathrm{m} 2$, sedangkan tegangan geser tebing diperoleh $\tau_{-} \mathrm{m}=10,93 \mathrm{~kg} / \mathrm{m} 2$. Adapun nilai tegangan geser kritis dasar saluran yang diperoleh $\tau_{-} \mathrm{c}=60,288 \mathrm{~kg} / \mathrm{m} 2$, sedangkan nilai tegangan geser kritis tebing yang diperoleh adalah $\tau \_\mathrm{s}=33,69 \mathrm{~kg} / \mathrm{m} 2$.

Hasil dari perhitungan menunjukkan bahwa nilai $\tau$ b lebih kecil dari nilai $\tau \mathrm{c}$ dan $\tau$ m lebih kecil dari $\tau \mathrm{s}$, maka desain ukuran batu dapat diterima yaitu dengan ukuran $40 \mathrm{~cm}$ atau 0,4 $\mathrm{m}$. Dari hasil perhitungan desain dan ukuran bronjong yang sesuai untuk studi perencanaan ini adalah bronjong bentuk I kode D. Bangunan bronjong terdiri dari struktur bronjong yang dibangun sedalam $13 \mathrm{~m}$ dari elevasi muka tanah. Struktur bronjong tersusun dari beberapa kotak bronjong dengan dimensi 2,0 x 1,0 x 1,0 meter, gambar desain bronjong tersebut ditampilkan sebagai berikut. 


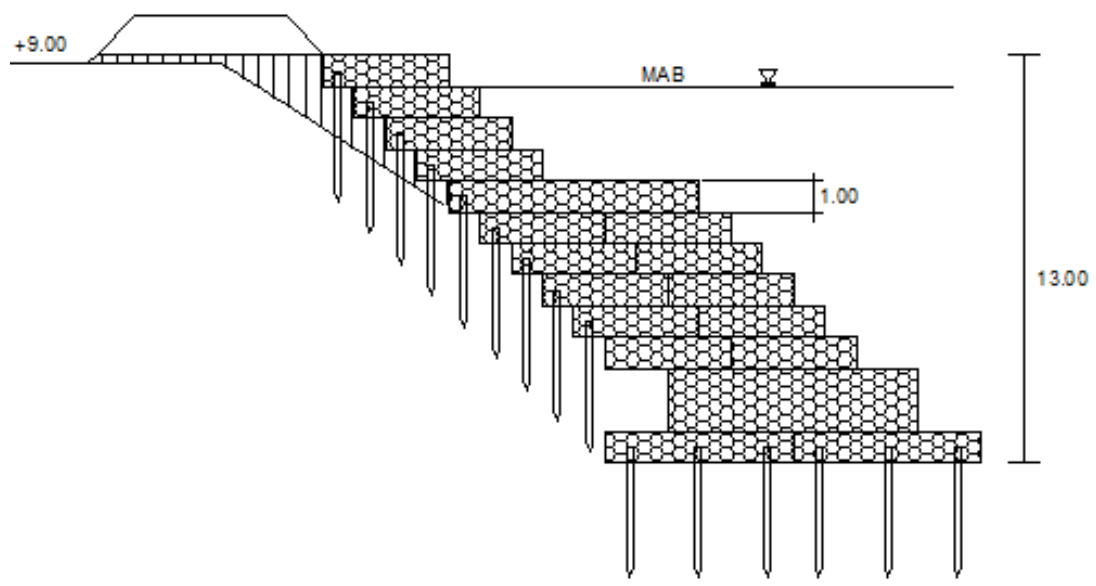

Gambar 3. Desain bangunan bronjong yang direncanakan dibuat untuk melindungi erosi tebing sungai bagian tikungan di Desa Meunasah Buloh

\subsection{Analisa stabilitas bangunan bronjong}

Analisa stabilitas bangunan perkuatan tebing sungai bronjong dihitung untuk mendapatkan konstruksi yang stabil terhadap gaya-gaya yang bekerja pada bronjong. Gaya - gaya yang bekerja pada bronjong meliputi gaya yang terjadi akibat berat sendiri bangunan (W), akibat tekanan tanah (Pa dan Pp), serta akibat tekanan hidrostatis $(\mathrm{H})$. Gaya yang diakibatkan dari tekanan tanah lateral menggunakan Rumus Rankine dengan langkah awal dihitung nilai tekanan tanah aktif dan tekanan tanah pasif. Langkah-langkah menghitung nilai Tekanan Tanah aktif $(\mathrm{Pa})$ sebagai berikut.

$$
\begin{aligned}
& k_{a}=\frac{1-\sin \theta}{1+\sin \theta} \\
& k_{a}=\frac{1-\sin 10}{1+\sin 10}=0,148 \\
& P_{a}=\frac{1}{2} \times H^{2} \times k a \times \gamma \mathrm{s} \\
& P_{a}=\frac{1}{2} \times 13^{2} \times 0,148 \times 2,2=27,505
\end{aligned}
$$

Langkah-langkah menghitung nilai Tekanan Tanah pasif (Pp) sebagai berikut.

$$
\begin{aligned}
& k_{p}=\cos \beta \frac{\cos \beta+\sqrt{\cos ^{2} \beta-\cos ^{2} \theta}}{\cos \beta-\sqrt{\cos ^{2} \beta-\cos ^{2} \theta}} \\
& k_{p}=\cos 45 \frac{\cos 45+\sqrt{\cos ^{2} 45-\cos ^{2} 10}}{\cos 45-\sqrt{\cos ^{2} 45-\cos ^{2} 10}}
\end{aligned}
$$


$k_{p}=0.707 \frac{0.707+\sqrt{0.5-0.24}}{0.707-\sqrt{0.5-0.24}}$

$k_{p}=0.116$

$P_{p}=\frac{1}{2} x H^{2} x k p x \gamma \mathrm{s}$

$P_{p}=\frac{1}{2} \times 2,87^{2} \times 0,116 \times 2,2=0,327$

Gaya-gaya yang bekerja pada bangunan bronjong yang terdiri meliputi gaya yang terjadi akibat berat sendiri bangunan (W), akibat tekanan tanah (Pa dan Pp), serta akibat tekanan hidrostatis $(\mathrm{H})$. ditampilkan pada Gambar 4. Untuk rekapitulasi perhitungan akibat 3 gaya yang bekerja pada bangunan bronjong ditampilkan pada Tabel 2.

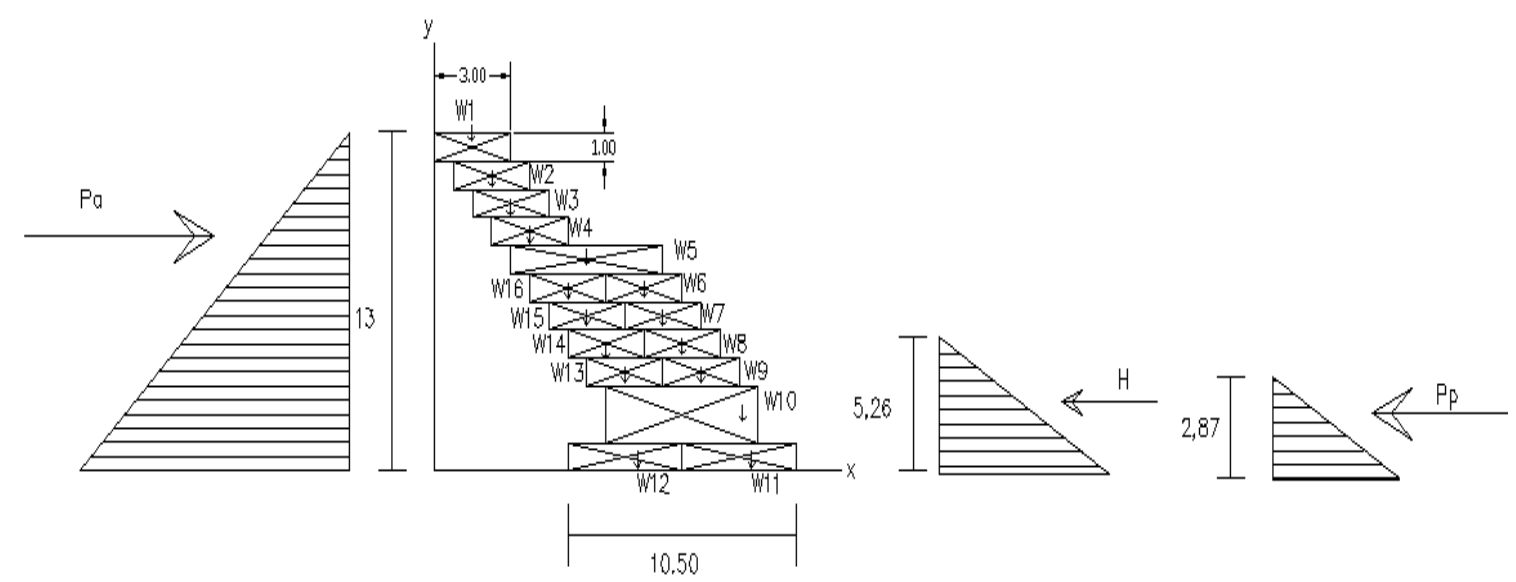

Gambar 4. Gaya-gaya yang bekerja pada bangunan bronjong

Tabel 2. Rekapitulasi gaya yang bekerja pada bangunan bronjong

\begin{tabular}{cccccc}
\hline \multirow{2}{*}{ No } & \multirow{2}{*}{ Gaya } & $\mathrm{H}$ & $\mathrm{V}$ & \multicolumn{2}{c}{ Momen } \\
\cline { 3 - 6 } & Berat sendiri & (ton ) & ( ton ) & $\mathrm{M}^{+}$ & $\mathrm{M}^{-}$ \\
\hline 1 & & 164,205 & & 842,76 \\
\hline 2 & Tekanan Lateral Tanah & 27,53 & & 99,032 & \\
\hline 3 & Gaya Hidrostatis & 44,94 & & 141,995 & \\
\hline \multicolumn{2}{c}{ Total } & 72,59 & 164,205 & 241,028 & 842,76 \\
\hline & & $\Delta \mathrm{M}=$ & 601,73 & $\mathrm{tm}$ \\
\hline
\end{tabular}

Hasil perhitungan gaya - gaya yang bekerja pada bronjong ini digunakan untuk menghitung analisa stabilitas pada bronjong. Perhitungan analisa stabilitas yang ditinjau antara lain:

a. Stabilitas terhadap guling

Konstruksi bronjong dinyatakan aman terhadap guling apabila nilai perbandingan momen penahan guling $\left(M_{t}\right)$ dengan momen guling $\left(M_{g}\right)$ lebih besar dari nilai SF 1,5. Nilai stabilitas terhadap guling dapat diperoleh FS $_{\text {guling }}$ sebesar 3,49. Berdasarkan hasil perhitungan dapat dilihat bahwa struktur konstruksi bronjong aman terhadap guling.

b. Stabilitas terhadap geser 
Konstruksi bronjong dinyatakan aman terhadap geser apabila perbandingan besar gaya yang bekerja secara vertikal pada sekeliling bangunan $(\Sigma \mathrm{V})$ dengan besar gaya yang bekerja secara horizontal pada sekeliling bangunan $(\Sigma \mathrm{H})$ lebih besar dari nilai SF 1,5. Hasil perhitungan stabilitas terhadap geser diperoleh $\mathrm{FS}_{\text {geser }}$ sebesar 1,58. Berdasarkan hasil perhitungan dapat dilihat bahwa struktur konstruksi bronjong aman terhadap geser.

c. Kontrol terhadap daya dukung tanah

Perhitungan daya dukung tanah terhadap pondasi dihitung dengan menggunakan data tanah pada lokasi perencanaan, meliputi berat jenis tanah, nilai kohesi, serta nilai sudut geser tanah. Langkah awal dalam melakukan kontrol terhadap daya dukung tanah adalah menentukan eksentrisitas, selanjutnya dihitung nilai tegangan izin yang dijadikan sebagai nilai acuan apakah konstruksi aman terhadap runtuhan.Jika nilai tegangan maksimum dari konstruksi lebih kecil dari nilai tegangan izin, maka konstruksi aman terhadap runtuhan. Nilai kapasitas dukung ultimit yang diperoleh sebesar $16,84 \mathrm{~kg} / \mathrm{cm}^{2}$ sedangkan tegangan maksimum yang diperoleh adalah 2,570 $\mathrm{kg} / \mathrm{cm}^{2}$. Hasil perhitungan diperoleh $\tau_{\max }$ lebih kecil dari $\tau_{\text {izin }}$ maka daya dukung tanah untuk pondasi bronjong sebagai perkuatan tebing sungai aman. Berikut hasil penggambaran desain dimensi Bronjong.

\section{SIMPULAN DAN SARAN}

Adapun beberapa kesimpulan yang diperoleh dari studi ini adalah sebagai berikut.

1. Analisa hidrologi didapatkan nilai debit banjir periode ulang 25 tahun sebesar $1153.19 \mathrm{~m} 3 / \mathrm{s}$.

2. Desain dan ukuran bronjong yang sesuai untuk studi perencanaan ini adalah bronjong bentuk I kode D dengan ukuran batu sebesar $40 \mathrm{~cm}$.

3. Struktur bronjong tersusun dari beberapa kotak bronjong dengan dimensi $2,0 \mathrm{x}$ $1,0 \times 1,0 \mathrm{~m}$.

4. Hasil perhitungan stabilitas terhadap guling diperoleh FSguling sebesar 3,49 dimana nilai ini lebih besar dari 1,5. Berdasarkan hasil perhitungan dapat dilihat bahwa struktur konstruksi bronjong aman terhadap gaya guling.

5. Hasil perhitungan stabilitas bronjong terhadap gaya geser diperoleh struktur konstruksi bronjong aman terhadap geser dimana nilai FSgeser sebesar 1,58 dimana nilai ini lebih besar dari 1,5.

6. Peletakan bangunan bronjong pada tebing sungai bagian tikungan/belokan sungai di Desa Meunasah Buloh mulai cross sungai A11 - A19 sepanjang $620 \mathrm{~m}$.

7. Hasil perhitungan diperoleh $\tau$ _max lebih kecil dari $\tau$ _izin maka daya dukung tanah untuk pondasi bronjong sebagai perkuatan tebing sungai aman.

Adapun saran yang diberikan pada studi ini, untuk penelitian selanjutnya dapat dilakukan studi dengan jenis perkuatan tebing sungai lainnya pada tebing sungai di Desa Meunasah Buloh. Selain itu juga, jumlah sampel tanah dapat diambil lebih dari beberapa titik tinjauan.

\section{UCAPAN TERIMAKASIH}

Rasa syukur kami sampaikan kehadirat Allah SWT karena berkat kemurahan-Nya karya ilmiah ini dapat kami selesaikan. Terima kasih kepada sesama tim penelitian yaitu Bu Dewi Purnama Sari, ST., M.Eng dan mahasiswa yang dilibatkan yang telah bekerja sama dan 
membantu dalam penyelesaian studi ini. Semoga karya ilmiah ini bermanfaat bagi pengembangan ilmu pengetahuan.

\section{DAFTAR PUSTAKA}

Asdak C. (2010). Hidrologi dan Pengelolaan Daerah Aliran Sungai. Gadjah Mada University Press, Yogyakarta.

Benyamin, E.A. (2017). Perkuatan Tebing Sungai Menggunakan Bronjong Di Sungai Manikin. Jurnal Teknik Sipil, Vol. VI, No. 2, pp. 187-198.

Dinas Pekerjaan Umum. (1999). Spesifikasi Bronjong Kawat, SNI 03-0090-1999. Dinas Pekerjaan Umum Pusat Litbang Prasarana Transportasi dan Pengembangan, Jakarta.

Freeman, G. E. and Fischenich J.C. (2000). Bronjongs for Streambank Erosion Control. Army Engineer Waterways Experiment Station Vicksburg Ms Engineer Research and Development Center, United States.

Hardiyatmo, H.C. (2011). Analisis dan Perencanaan Fondasi II. Edisi Kedua. Gadjah Mada University Press, Yogyakarta.

Harto, S. (2000). Analisis Hidrologi. PT. Gramedia, Jakarta.

Kodoatie, R. dan Sugyanto. (2002). Banjir, Beberapa Penyebab dan Metode Pengendaliannya. Pustaka Pelajar, Yogjakarta.

Murri, M. M., Surjandari, N. S., dan As'ad, S. (2014). Analisis Stabilitas Lereng dengan Pemasangan Bronjong (Studi Kasus di Sungai Gajah Putih, Surakarta). e-Jurnal Matriks Teknik Sipil, Vol. 2, no. 1, pp. 162-169.

Rosihun, M. dan Endaryanta. (2011). Analisis Stabilitas Talud Bronjong Sungai. UIN Sunan Kalijaga Yogyakarta, Jurnal Inersia, Vol. : VII, No. 2. pp. 182-201.

Triatmodjo. (2010). Hidraulika II. Beta Offset, Yogyakarta. 